OPEN ACCESS

Edited by:

Cheng Zhong,

Tianjin University, China

Reviewed by:

Abhishek Lahiri,

Brunel University London,

United Kingdom

Dillip K. Panda,

Clemson University, United States

*Correspondence:

Nosang V. Myung

nmyung@nd.edu

${ }^{\dagger}$ Deceased

Specialty section:

This article was submitted to Electrochemistry,

a section of the journal

Frontiers in Chemistry

Received: 13 April 2021

Accepted: 21 June 2021

Published: 01 September 2021

Citation:

Wei JC, Schwartz M, Nobe K and

Myung NV (2021) Aqueous Electrodeposition of SmCo Alloys: II.

Direct Current Studies.

Front. Chem. 9:694726.

doi: 10.3389/fchem.2021.694726

\section{Aqueous Electrodeposition of SmCo Alloys: II. Direct Current Studies}

\author{
Jei C. Wei ${ }^{1}$, Morton Schwartz ${ }^{1 \dagger}$, Ken Nobe ${ }^{1 \dagger}$ and Nosang V. Myung ${ }^{2 *}$ \\ ${ }^{1}$ University of California at Los Angeles, Los Angeles, CA, United States, ${ }^{2}$ University of Notre Dame, Notre Dame, IN, \\ United States
}

Previously, we reported the aqueous electrodeposition of rare earth - iron group alloys. A key factor was the complexation of the metal ions with various coordination compounds (e.g., aminoacetic acids), without which only the ferrous metal and rare earth hydroxides/ oxides are deposited. In this work, samarium cobalt (SmCo) alloys were synthesized using direct current (DC) aqueous electrodeposition. The basic electrolyte solution consisted of $1 \mathrm{M}$ samarium sulfamate, $0.05 \mathrm{M}$ cobalt sulfate, and $0.15 \mathrm{M}$ glycine, resulting in deposits containing $>30$ at $\% \mathrm{Sm}$ at $60^{\circ} \mathrm{C}$ with current density of $500 \mathrm{~mA} / \mathrm{cm}^{2}$. Supporting electrolytes (i.e., ammonium salts) decreased the Sm content in the deposit. Crystallinity of deposited films altered from nanocrystalline to amorphous as the Sm content increased. Deposits with high $\mathrm{Sm}$ content (32 at\%) became isotropic with reduction in magnetic saturation $\left(M_{s}\right)$ and coercivity $\left(H_{c}\right)$. A deposition mechanism involving stepwise reduction of the complexed Sm-Co ions by depositing hydrogen atoms was proposed.

Keywords: electrodeposition, samarium cobalt, magnetic thin films, glycine, aqueous

\section{INTRODUCTION}

High-performance permanent magnets such as samarium-cobalt ( $\mathrm{SmCo}$ ) and neodymium-ironboron $(\mathrm{NdFeB})$ alloys are playing an increasingly prominent role in miniaturizing electrical and electronic machines and devices. Although the rare earth-transition metals (RE-TM) alloys are substantially more expensive than the hard, magnetic ferrites, their superior magnetic properties drive the RE-TM permanent magnets' growing usage (Strnat and Strnat, 1991). A sharp decline in their manufacturing costs would lead to an increasingly dominant position in worldwide applications of nano- and micro-scale systems.

Compared to SmCo, $\mathrm{NdFeB}$ permanent magnets $(\mathrm{PM})$ have a higher energy product $\left((\mathrm{BH})_{\max }\right)$ and coercivity $\left(\mathrm{H}_{\mathrm{c}}\right)$, but a lower Curie temperature $\left(\mathrm{T}_{\mathrm{C}}\right)$ and chemical stability in aggressive environments. As a result, SmCo PMs have application in high temperature and aggressive environments such as those encountered by military and aeronautical / aerospace systems (du Trémolet Lacheisserie et al., 2002). So far, fabrication of nanostructured SmCo alloys have been restricted to physico-chemical deposition methods. Therefore, development of an aqueous electrodeposition process would dramatically reduce manufacturing costs (Dini, 1993).

In a series of preliminary studies, we reported on the aqueous electrodeposition of alloys of RE mischmetals, La, Ce, Nd, Gd and Sm with the iron group metals (e.g., Ni, Co, and Fe). The key factor is the complexation of the metal ions with aminocarboxylates (Chen et al., 1996; Myung et al., 1999; Schwartz et al., 1999; Schwartz et al., 2004; Wei et al., 2006; Wei et al., 2008; Wei et al., 2009). The present work reports on the aqueous DC electrodeposition of SmCo alloys using parallel electrodes. The solution constituents and compositions as well as the deposition 


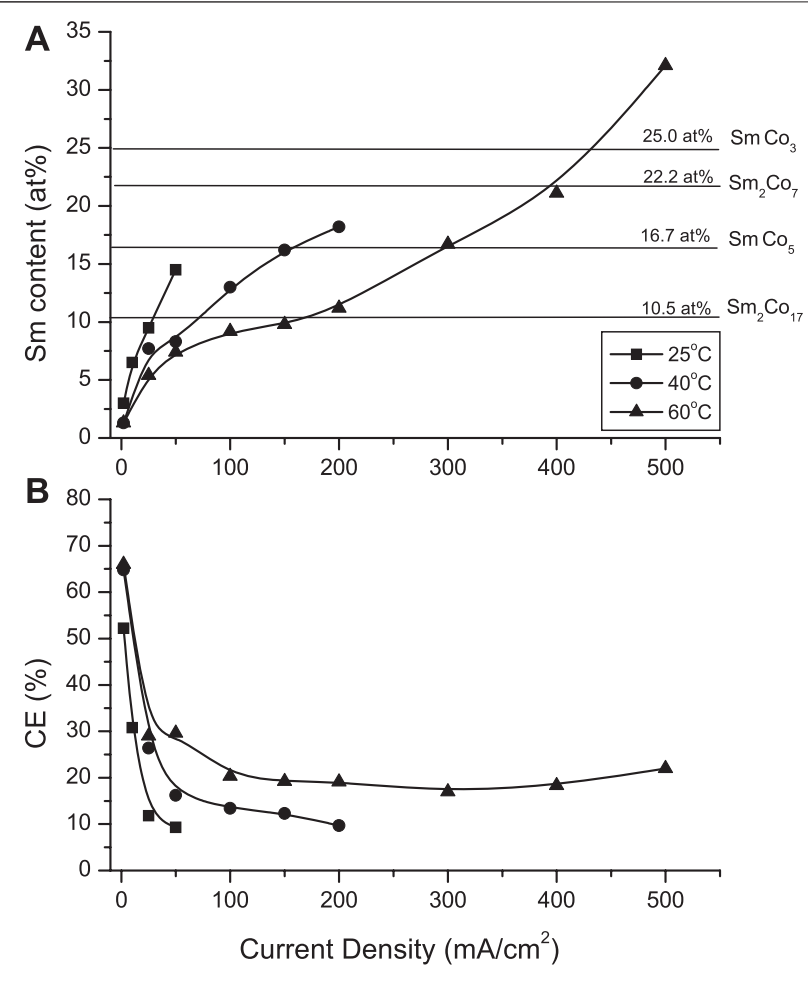

FIGURE 1 | Effect of current density and solution temperature on (A) deposit samarium content and (B) current efficiency (CE).

variables were selected as a result of preliminary parametric studies using Hull Cells (HC) (Wei et al., 2008).

\section{EXPERIMENTAL}

The electrodeposition cell consisted of two parallel electrodes (brass cathode, $2 \times 2 \mathrm{~cm}$, and a platinum anode, $3 \times 6 \mathrm{~cm}$ ), which were $4 \mathrm{~cm}$ apart. A shielding panel with a $2 \mathrm{~cm}$ by $2 \mathrm{~cm}$ window was inserted equidistant between the electrodes to provide a more uniform current distribution. A saturated calomel electrode (SCE) measured the cathode potential. A potentio/gavalno-stat (EG \& G 273) served as the power source with a coulometer measuring charge (50 C). Solution volume was kept at $240 \mathrm{ml}$. The basic solution consisted of $1 \mathrm{M}$ Sm sulfamate, $0.05 \mathrm{M}$ Co sulfate, and $0.15 \mathrm{M}$ glycine, unless otherwise noted. The plating conditions were varied within the following ranges: current density from 2 to $500 \mathrm{~mA} / \mathrm{cm}^{2}$, temperature from 25 to $60^{\circ} \mathrm{C}, \mathrm{pH}$ range from 2 to 6 . The solutions were not agitated during electrodeposition.

Prior to plating, the brass cathode was mechanically cleaned by immersing in $0.1 \mathrm{M} \mathrm{NaOH}$, rinsing with deionized (DI) water, dipping in 10 vol. \% $\mathrm{HCl}(30 \mathrm{~s})$ and then rinsed with DI water. The plated cathodes were rinsed and dried with nitrogen. Disk specimens $(0.64 \mathrm{~cm}$ diameter $)$ were fabricated for analysis and characterization.

$\mathrm{Sm}$ and Co contents in the deposits were determined by energy dispersive X-ray spectroscopy (EDS). Co content was

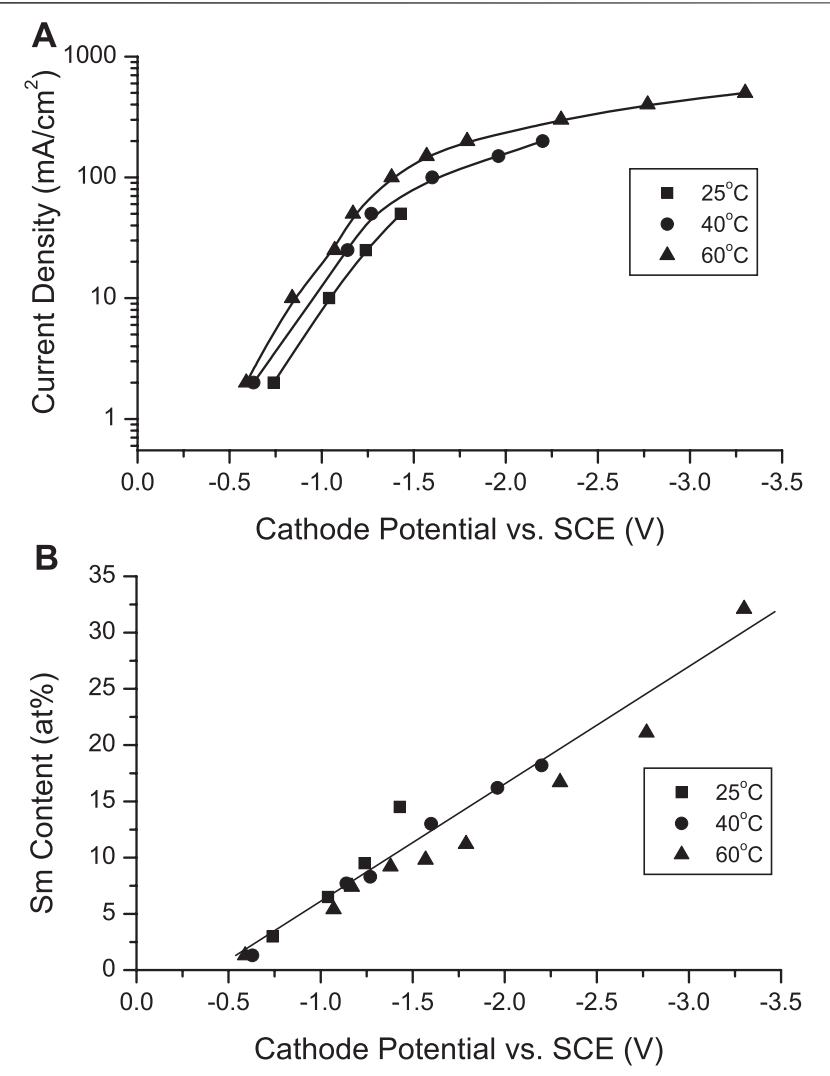

FIGURE 2 | (A) Cathodic polarization curves in the electrodeposition of Sm-Co alloys at various current densities and solution temperature and (B) dependence of Sm content on cathodic potential.

measured separately by atomic absorption spectrophotometry (AAS, Perkin Elmer). Deposit structure, crystal orientation, phase identification and grain size were determined by powder $\mathrm{X}$-ray diffraction (XRD). Deposit surface morphology and microstructure were observed with scanning electron microscopy (SEM). Magnetic properties were determined by a vibrating sample magnetometer (VSM, Digital Measurement Systems Model 1660) with an applied magnetic field scanning between -10 and +10 KOe. In-phase $(/ /)$ and perpendicular $(\perp)$ measurements represent the field applied to the specimen's plane, respectively. The deposit magnetic properties were obtained from $\mathrm{BH}$ loops. All measurements and data reported were on deposits with metallic appearance, unless otherwise noted. $C D_{\max }$ is the maximum current density, beyond which deposits appeared non-metallic. Minimum duplicate runs were performed.

\section{RESULTS AND DISCUSSION}

Confirming trends of the Hull Cell (HC) studies (Wei et al., 2008), the deposit Sm content increased with increasing temperature and applied current density (Figure 1A). At $25^{\circ} \mathrm{C}$, the $\mathrm{CD}_{\max }$ was $50 \mathrm{~mA} / \mathrm{cm}^{2}$ with deposit containing approximately 14.5 at $\% \mathrm{Sm}$ (i.e., $30.2 \mathrm{wt} \%$ ). Increased 


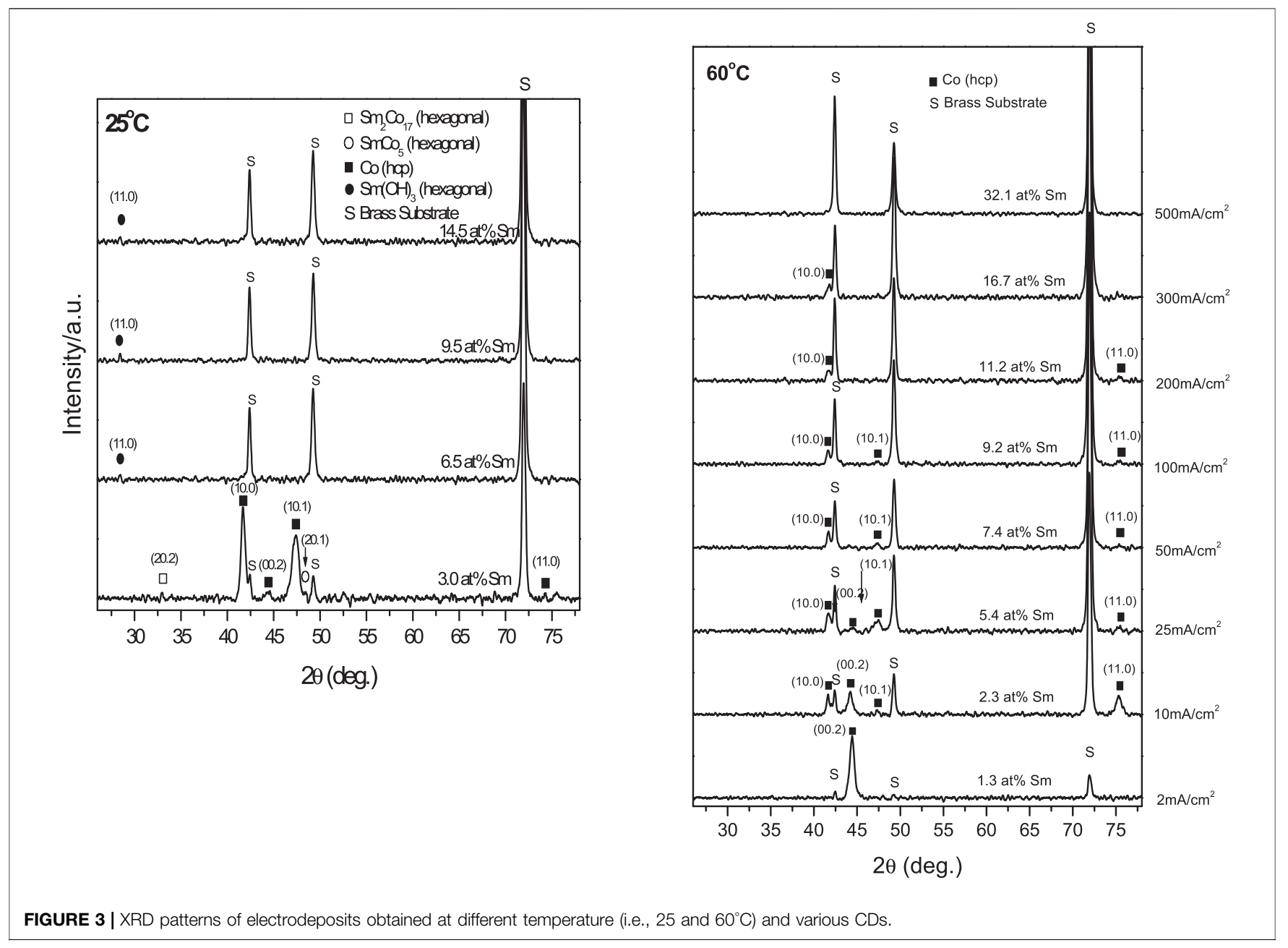

solution temperature $\left(60^{\circ} \mathrm{C}\right)$ extended the $\mathrm{CD}_{\max }$ to $500 \mathrm{~mA}$ / $\mathrm{cm}^{2}$, resulting in the deposit $\mathrm{Sm}$ content of approximately 30 at\% (i.e., $55 \mathrm{wt} \%$ ), sufficient for a series of stoichiometric SmCo intermetallic compounds (after appropriate annealing): $\mathrm{Sm}_{2} \mathrm{Co}_{17}, \mathrm{SmCo}_{5}, \mathrm{SmCo}_{7}$ and $\mathrm{SmCo}_{3}$. The current efficiencies (CEs) initially decreased sharply, leveling with $\mathrm{CD}$ exceeding $50 \mathrm{~mA} / \mathrm{cm}^{2}$ (Figure 1B).

While the cathode potential became more negative with increased $\mathrm{CD}$, it was less negative with increased solution temperature (Figure 2A). The deposit Sm content increased linearly with more negative potentials, apparently independently of solution temperature (Figure 2B). However, co-deposition of SmCo initiating a potential less negative than the equilibrium potential of $S m\left(E_{S m / s m}^{o}{ }^{3+}=-2.65\right.$ vs SCE $)$ indicated a deposition mechanism involving a potential resulting from complexation rather than direct electrodeposition from aqueous ions.

X-ray diffraction spectra (XRD) of Figure 1 deposits indicated structures changing from crystalline to noncrystalline (amorphous) with increasing Sm content (Figure 3). The crystolites consisted of $\alpha$-Co phases (hexagonal close packed (hcp)) or Sm (rhombohedral) phases were observed. Deposits formed at $25^{\circ} \mathrm{C}$ were essentially amorphous with low $\mathrm{Sm}(\mathrm{OH})_{3}$ content. Low $\mathrm{CD}$ $\left(2 \mathrm{~mA} / \mathrm{cm}^{2}, 3\right.$ at $\left.\% \mathrm{Sm}\right)$ deposit showed strong 10.0 and $10.1 \alpha$ Co (hcp) peaks and weak (20.1), (20.2) $\mathrm{SmCo}_{5}$ and $\mathrm{Sm}_{2} \mathrm{Co}_{17}$ (hcp) peaks, respectively (Figure 3 ).

$\mathrm{XRD}$ spectra of $60^{\circ} \mathrm{C}$ electrodeposits (not shown) indicated a slight shift in the Bragg angles ( $\alpha$-Co 0.002 and 10.0 peaks) with increasing Sm content. Differing atomic radii of Co $(1.25 \AA)$ and Sm $(1.81 \AA)$ suggested a misfit, $(\mathrm{RSm}-\mathrm{RCo})=0.45$ ], which could result in Co lattice distortion, which tends to elongate the Co lattice while compressing it along the basic plane and likely generate residual stresses in the SmCo deposit contributing to microcracks (Figure 4).

Figure 4 shows the SEM images of SmCo alloys electrodeposited at $60^{\circ} \mathrm{C}$ and $100 \mathrm{~mA} / \mathrm{cm}^{2}$, which revealed a cracked nodular surface. At higher magnification, fibrous nanorods with varying random orientation emanating from individual nodules (Figures 4B,C) were observed, as with other electrodeposited cobalt and cobalt alloys (Cavallotti et al., 1983). The estimated nodule diameters ranged 

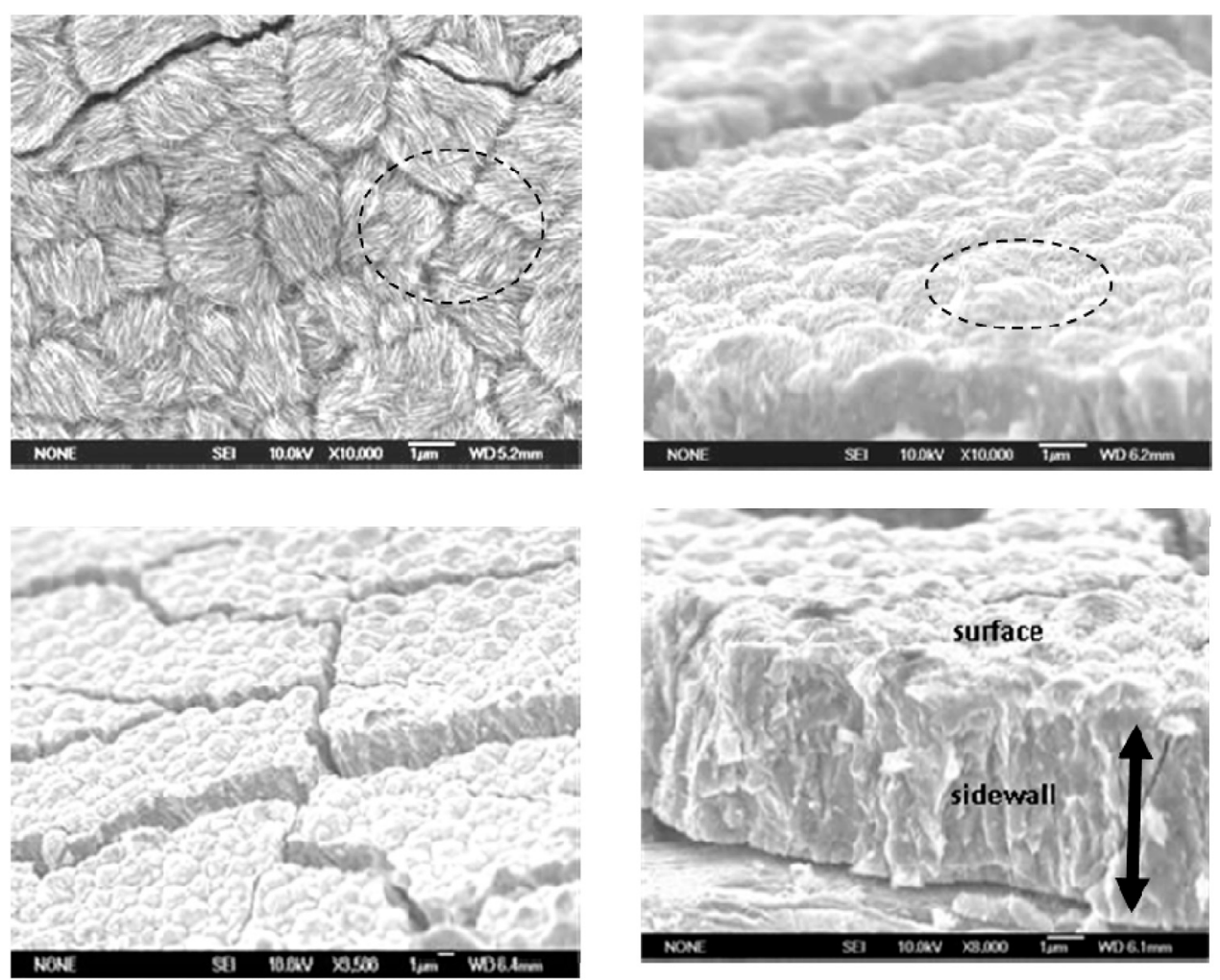

FIGURE 4 | Top and cross-sectional scanning electron microscopic images of Sm-Co electrdeposits at different magnification; 9.2 at $\% \mathrm{Sm}, \sim 5 \mu \mathrm{m}, \mathrm{pH} 5.7,60^{\circ} \mathrm{C}$, $100 \mathrm{~mA} / \mathrm{cm}^{2}$

approximately from 1.5 to $2.5 \mu \mathrm{m}$, the crack widths from 0.12 to $0.15 \mu \mathrm{m}$ with an estimated density of approximately $1,000 \mathrm{cracks} / \mathrm{cm}^{2}$. The texture of the mechanically fractured sidewall was indicative of the deposit's brittleness (Figure 4D). It is suggested that the deposit nanocrystalline or amorphous structure and columnar growth may be the result of coalescing or bundling fibers (Figure 4C). Experience with electrodeposits of chromium (Cr) and electroless nickel (Ni) indicated that fine-grained nanocrystalline or amorphous deposit surfaces generally contain nodules (Ruan and Schuh, 2008).

Figures 5, 6 show the effects of deposition variables on deposit composition and magnetic properties. Hysteresis loops indicated magnetic saturation $\left(\mathrm{M}_{\mathrm{s}}\right)$ was easier along the in-plane direction (easy axis) than the perpendicular direction (hard axis). The in-plane and perpendicular directions approached each other as deposit $\mathrm{Sm}$ content increased, while $\mathrm{M}_{\mathrm{s}}$ and $\mathrm{H}_{\mathrm{c}}$ decreased as $\mathrm{CD}$ increased. At constant $\mathrm{CD}$ and increased solution temperature $\left(25^{\circ} \mathrm{C}-60^{\circ} \mathrm{C}\right), \mathrm{M}_{\mathrm{s}}$ and $\mathrm{H}_{\mathrm{c}}$ increased, reflecting changing alloy compositions and structures (Figure 5)

Magnetization $\left(M_{s}\right)$ decreased linearly with increased deposit Sm content (Figure 6B), similar to sputtered deposits (Cho et al., 1997). Magnetic saturation of Co $\left(M_{s}=169 \mathrm{emu} / \mathrm{g}\right)$ (Bozorth, $1978)$ is higher than $\operatorname{Sm}\left(M_{s}=0.3 \mathrm{emu} / \mathrm{g}\right)$ (Adachi et al., 1994), and the decreased $M_{s}$ of the alloy was the result of decreased Co content. The deposit's structure changed from crystallinity to non-crystallinity with increased Sm content (Figure 6). Deposits with low Sm contents exhibited (002) plane orientation ( $c$-axis), resulting in anisotropy.

As the deposit structure changes from crystallinity to noncrystallinity (increased Sm content), the deposits become more isotropic (Figure 5), and $\mathrm{M}_{\mathrm{s}}$ and $\mathrm{H}_{\mathrm{c} \|}$ decreased. Deposits with low $\mathrm{Sm}$ contents exhibit 00.2 plane orientation ( $c$-axis), resulting in anisotropy $\left(\mathrm{H}_{\mathrm{c} \perp}>>\mathrm{H}_{\mathrm{c} \|}\right)$ (Figure 6C). Deposits with increased Sm have decreased hcp 00.2 peak intensity with decreased $\mathrm{H}_{\mathrm{c} \perp}$. Deposits with high Sm content (32 at\%) are non-crystalline and isotropic $\left(\mathrm{H}_{\mathrm{c} \perp} \approx \mathrm{H}_{\mathrm{c} \|}\right)$ as shown in Figure $6 \mathrm{C}$ with reduced $\mathrm{M}_{\mathrm{s}}$ (Figure 6B).

Deposit coercivities in the in-plane direction (100 Oe) varied only slightly with deposit composition, but in the perpendicular direction, higher $\mathrm{H}_{\mathrm{c}}$ (600-800 Oe) was obtained at low Sm content, decreasing sharply with increasing deposit Sm content. We note that as-deposited room temperature sputtered stoichiometric SmCo films also exhibited low coercivities $(\sim 100 \mathrm{Oe})$, which did not increase substantially with subsequent annealing unless deposited on a $\mathrm{Cr}$ underlayer, promoting nanocrystalline c-axis texture in the SmCo deposit, increasing in-plane anisotropy $\left(\mathrm{H}_{\mathrm{c}}>40 \mathrm{KOe}\right)$ (Prados and Hadjipanayis, 1998; Prados and Hadjipanayis, 1999). 


\section{$25^{\circ} \mathrm{C}$}
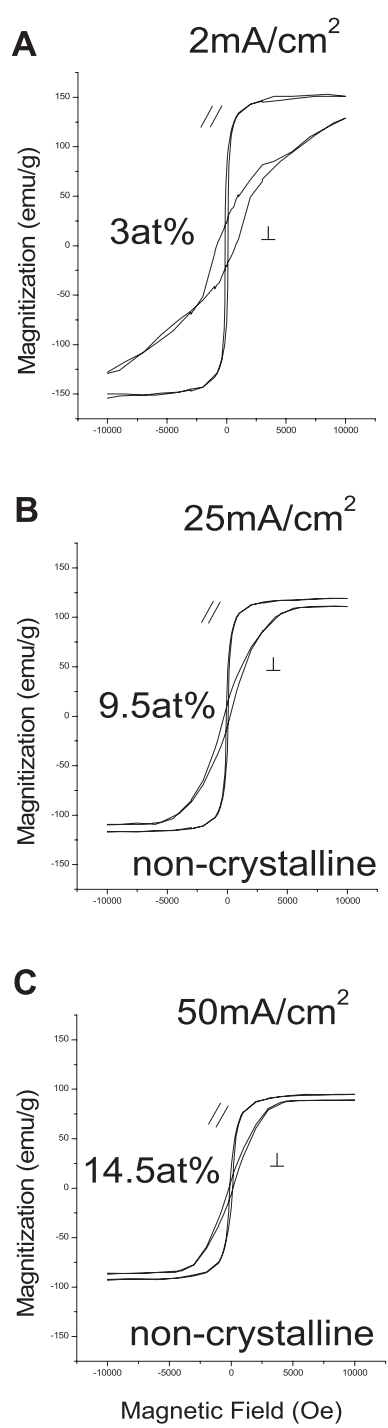

$60^{\circ} \mathrm{C}$
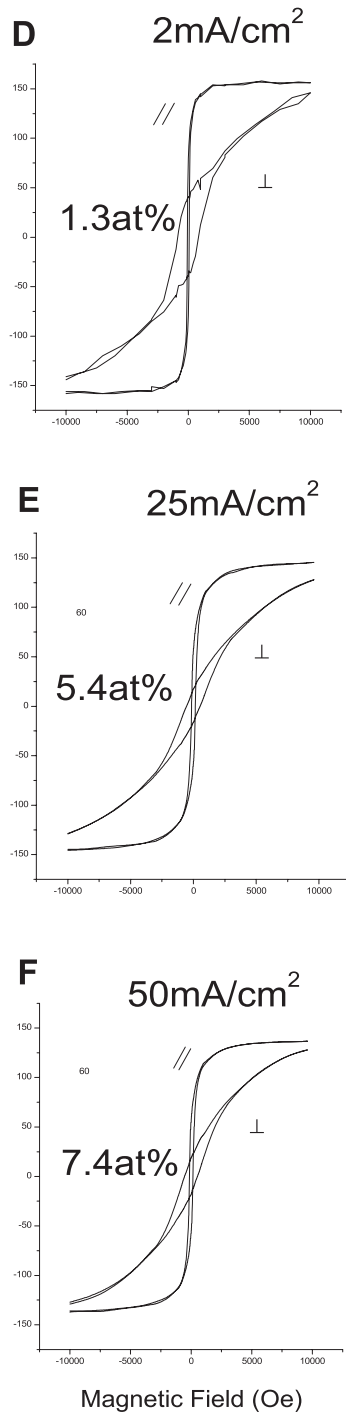

$60^{\circ} \mathrm{C}$
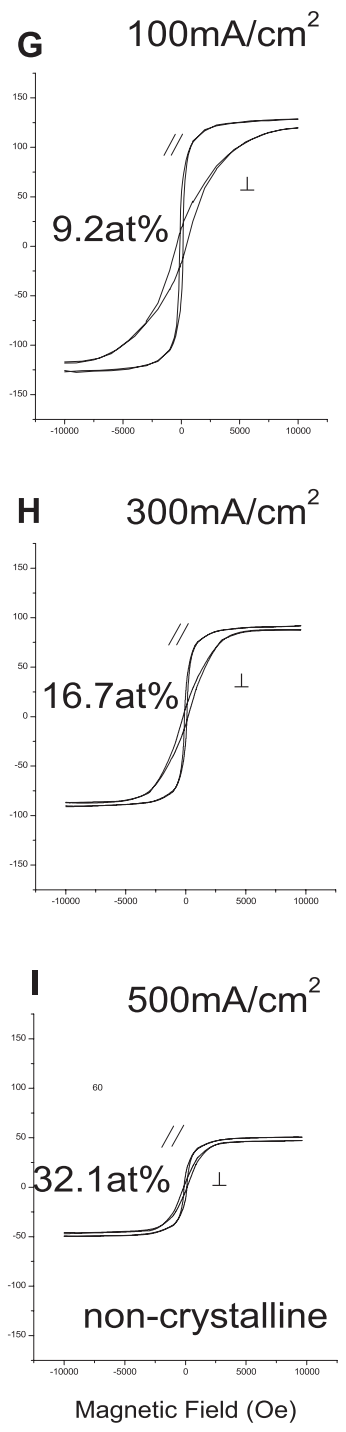

FIGURE 5 | Magnetic hysteresis loops of Sm-Co deposits at 25 and $60^{\circ} \mathrm{C}$, and various CDs.

In-plane coercivities remained constant regardless of the deposit Sm content; coercivity in the perpendicular direction, however, decrease with increased Sm content (Figure 6C). The squareness of the deposits appeared to be reversed (Figure 6D).

Deposit particle size decreased as Sm content increased, result of increased $\mathrm{CD}$ and/or decreased solution temperature (Figure 6A). Cavallotti et al. reported similar results for electrodeposited Co and Co alloys (Cavallotti et al., 1983).

Figure 7A shows the dependence of Sm content on $\mathrm{pH}$ at various $\mathrm{CDs}\left(10\right.$ and $\left.50 \mathrm{~mA} / \mathrm{cm}^{2}\right)$ at room temperature. $\mathrm{Sm}$ contents were higher than at $60^{\circ} \mathrm{C}$ but at the latter temperature maxima deposit $\mathrm{Sm}$ content were higher between $\mathrm{pH} 4\left(12 \mathrm{at} \%, 100 \mathrm{~mA} / \mathrm{cm}^{2}\right)$ and $\mathrm{pH} 5\left(28\right.$ at. $\left.\%, 300 \mathrm{~mA} / \mathrm{cm}^{2}\right)$, respectively. Lower current densities and higher solution temperatures resulted in higher current efficiencies (CEs), but dependence on solution $\mathrm{pH}$ was not substantial (Figure 7B).

Hull cell experiments (Wei et al., 2008) showed Co and $\mathrm{Sm}(\mathrm{OH})_{3}$ are electrodeposited from glycene-free solution, indicating a complex was essential for deposition of SmCo alloys. At $25^{\circ} \mathrm{C}$, maximum deposit $\mathrm{Sm}$ contents were obtained at $25 \mathrm{~mA} / \mathrm{cm}^{2}\left(\sim 11\right.$ at\%) and $50 \mathrm{~mA} / \mathrm{cm}^{2}(\sim 14$ at $\%)$ with glycine concentration of 0.1 and $0.15 \mathrm{M}$, respectively; below $0.1 \mathrm{M}$, non-metallic deposits were formed. Increased solution temperature $\left(60^{\circ} \mathrm{C}\right)$ and higher $\mathrm{CDs}$ resulted in increased $\mathrm{Sm}$ contents (e.g., $300 \mathrm{~mA} / \mathrm{cm}^{2}, 0.1 \mathrm{M}$ glycine to $\sim 18$ at\%) initially, 

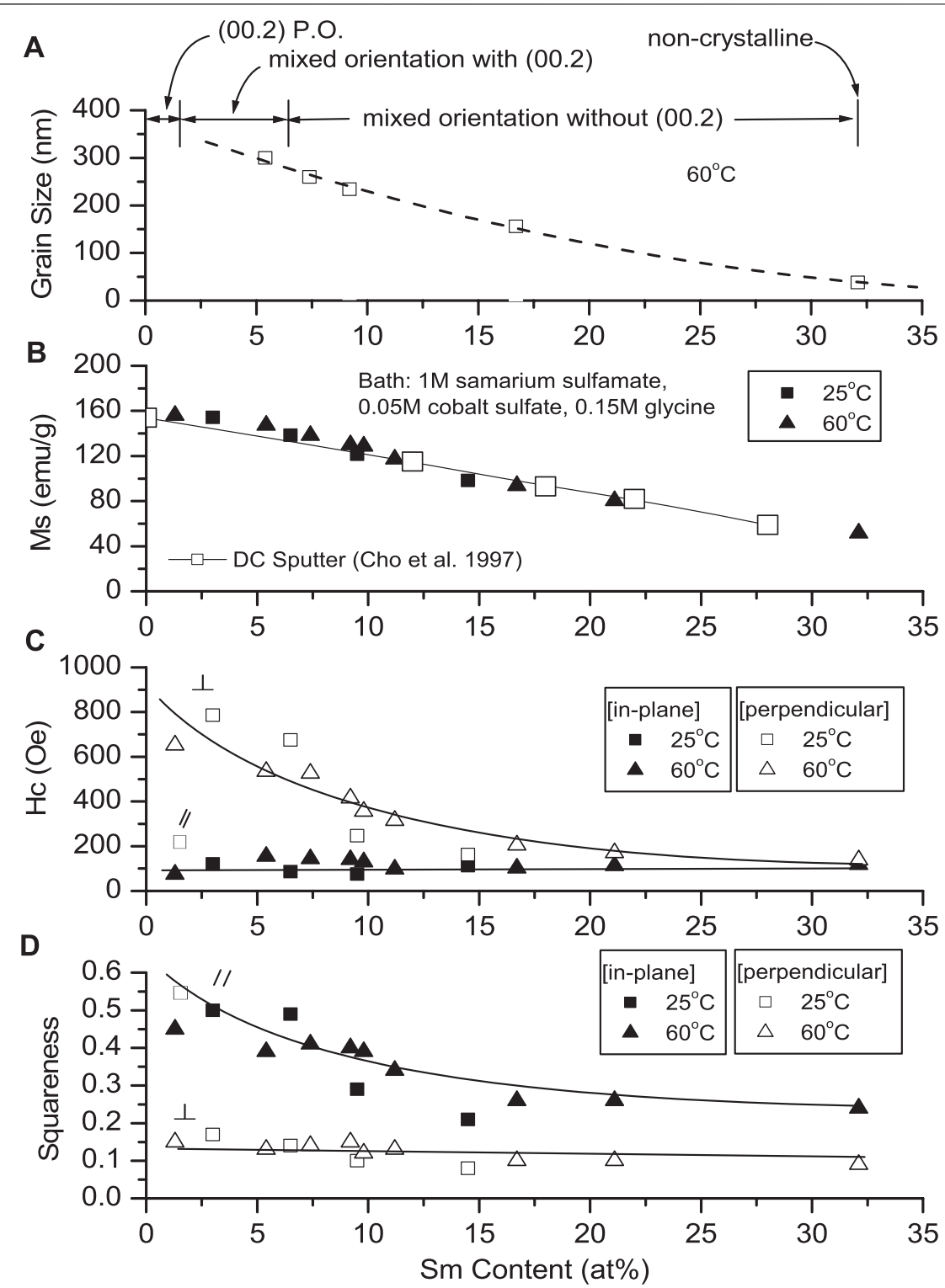

FIGURE 6 | Effect of Sm deposit content and temperature on grain size and magnetic properties.

decreasing with increased glycine concentration $(>0.1 \mathrm{M})$. High deposit Sm contents were obtained with 2 to $3: 1$ glycine to Co ratios in the presence of excess $\mathrm{Sm}^{3+}$ (Figure 8A).

Current efficiencies (CEs) of $25^{\circ} \mathrm{C}$ deposits increased to $15 \%$ with increased $\mathrm{CD}$ and glycine concentrations. At $60^{\circ} \mathrm{C}$, there appeared to be no significant $\mathrm{CE}$ dependence, although $\mathrm{CE}$ increased to $30 \%$ at higher CDs (Figure 8B).

$\mathrm{XRD}$ spectra (not shown) indicated that $0.15 \mathrm{M}$ glycine containing solutions produced nanocrystalline or amorphous deposits with a weak $11.0 \mathrm{Sm}(\mathrm{OH})_{3}$ peak at $25^{\circ} \mathrm{C}$ but none at $60^{\circ} \mathrm{C}$. This confirmed observations of the HC studies (Wei et al., 2008), i.e., glycine inhibited formation of hydroxides in agreement with Diven et al. (2003) that glycinato-Co complexes inhibit formation of $\mathrm{Co}(\mathrm{OH})_{2}$ in aqueous solutions.
Interestingly, XRD spectra of deposits from solutions with $0.05 \mathrm{M}$ or $0.5 \mathrm{M}$ glycine concentrations show the presence of $\mathrm{Sm}(\mathrm{OH})_{3}$ and $\mathrm{Co}(\mathrm{OH})_{2} 11.0$ peaks, which suggested an optimum concentration of complexant: $\mathrm{M}$ (metal ion) ratio, minimizing or inhibiting hydroxide/oxide inclusions. At $60^{\circ} \mathrm{C}$, deposits also exhibited several Co (hcp) peaks which did not appear in $25^{\circ} \mathrm{C}$ deposit spectra.

Figure 9 shows the effects of selected complexants $(0.15 \mathrm{M})$ on the deposit $\mathrm{Sm}$ contents. In $25^{\circ} \mathrm{C}$ solutions, only the amino acids appeared to be effective complexants (Table 1), while the other tested complexants resulted in burnt or powdery deposits containing hydroxides/oxides. Increasing solution temperature to $60^{\circ} \mathrm{C}$ resulted in extending the $\mathrm{CD}$ ranges and permitted codeposition with other amino acids and hydroxycarboxylic acids, 


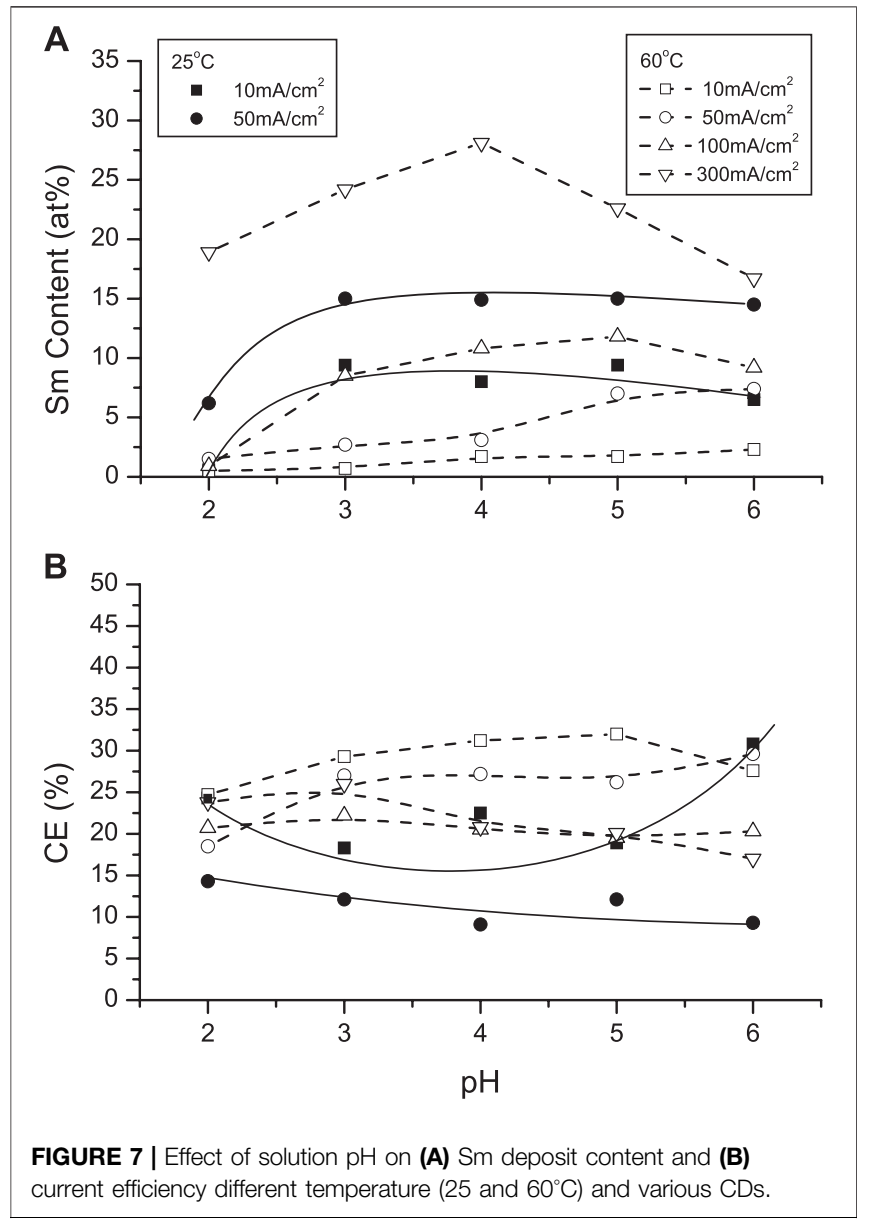

analogous to glycine and alanine (glycolic and lactic acids) with decreased $\mathrm{CD}_{\max }$ (Table 1). Substitution of other complexants for glycine indicated glycine provided higher deposit Sm contents, but polycarboxylic acids (e.g., citric acid, EDTA) presumably resulted in stronger complexes which prevented deposition of SmCo alloys. These results suggested the bond strengths and/or structures of the various (aqueous) coordination compounds and their interdependence with the deposition variables are paramount in the co-deposition of the alloys, their compositions and magnetic properties.

Supporting electrolytes (SE) are frequently added as solution components to increase solution conductivity, stabilize solution $\mathrm{pH}$, and permit higher CDs, affecting deposit composition and properties. Figure 10 shows the effect of $\mathrm{KCl}, \mathrm{NH}_{4} \mathrm{Cl}$ and $\mathrm{NH}_{4}$ sulfamate on deposit Sm content. At $25^{\circ} \mathrm{C}, \mathrm{KCl}$ increased the deposit Sm content up to 18 at\%, which was higher than that in the absence of supporting electrolyte (15-14 at\%), while $\mathrm{NH}_{4} \mathrm{Cl}$ and $\mathrm{NH}_{4}$ sulfamate decreased the Sm content to 9.7 at $\%$ and 8.1 at $\%$, respectively. $\mathrm{CD}$ increased substantially at $60^{\circ} \mathrm{C}$ in both the absence and presence of supporting electrolytes (Figure 10).

Ammonium compounds are widely added to plating solutions as these SE may participate in complexation of the depositing ions. Ammonium sulfamate was investigated as SE in the SmCo solutions (Figure 11). Increasing additions of $\mathrm{NH}_{4}^{+}(0-1 \mathrm{M})$
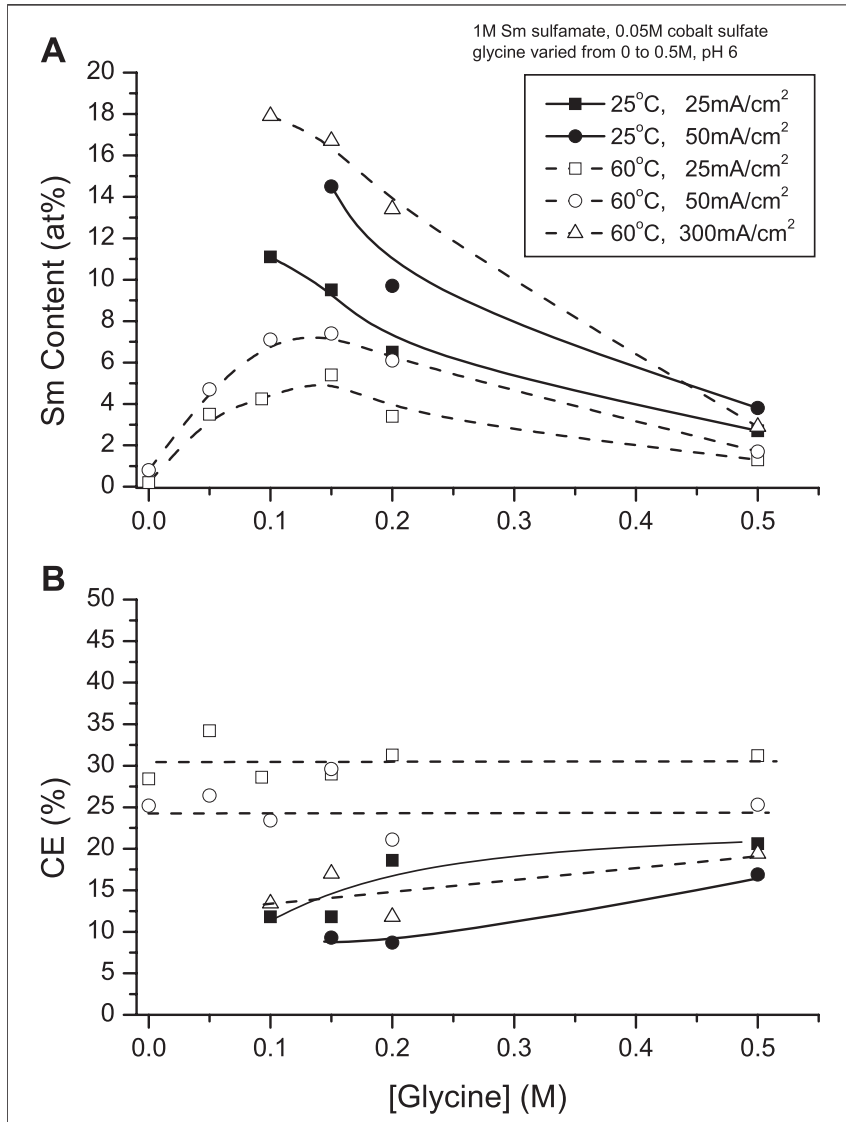

FIGURE 8 | Effect of glycine concentration on (A) samarium deposit content and (B) current efficiency at 25 and $60^{\circ} \mathrm{C}$.

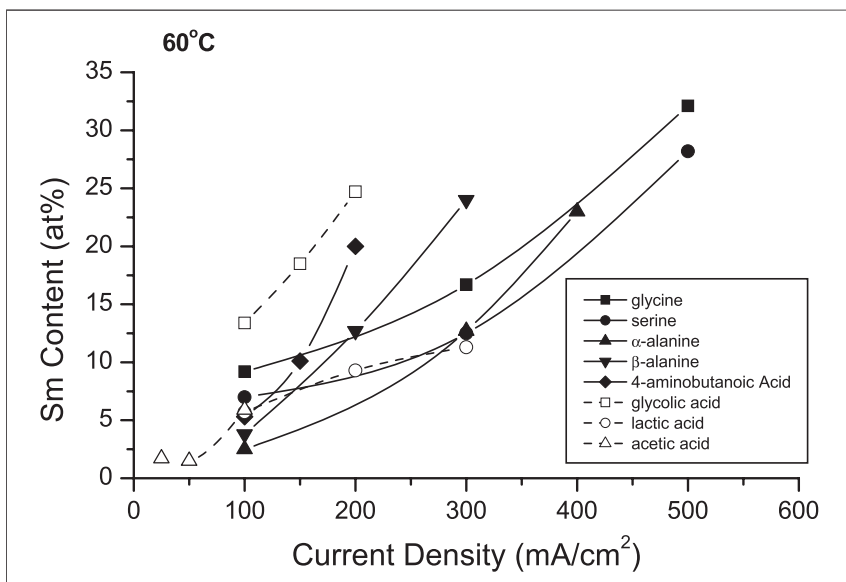

FIGURE 9 | Effect of various complexes on samarium deposit content at $60^{\circ} \mathrm{C}(\mathrm{pH}=5.8)$.

decreased the deposit $\mathrm{Sm}$ contents from solutions at both $25^{\circ} \mathrm{C}$ and $60^{\circ} \mathrm{C}$. This effect was more pronounced at the higher temperature: Sm deposit contents decreased from $\sim 32$ at. \% Sm (no $\mathrm{NH}_{4}^{+}$) to $\sim 11$ at $\% \mathrm{Sm}\left(1 \mathrm{M} \mathrm{NH}_{4}^{+}\right.$) at $500 \mathrm{~mA} / \mathrm{cm}^{2}$, with similar decreases at lower CDs. This might be attributed 
TABLE 1 | Summary of $\mathrm{CD}_{\max }$ and max. Sm contents obtained from solutions containing different complexers.

\begin{tabular}{|c|c|c|c|c|}
\hline \multirow[b]{2}{*}{ Complexer } & \multicolumn{2}{|c|}{$25^{\circ} \mathrm{C}$} & \multicolumn{2}{|c|}{$60^{\circ} \mathrm{C}$} \\
\hline & $C D_{\max }\left(\mathrm{mA} / \mathrm{cm}^{2}\right)$ & Max. Sm content (at\%) & $\mathrm{CD}_{\max }\left(\mathrm{mA} / \mathrm{cm}^{2}\right)$ & Max. Sm content (at \%) \\
\hline Acetic acid & nd & nd & 100 & 6 \\
\hline Glycine & 50 & 15 & 500 & 32 \\
\hline Serine & 50 & 13 & 500 & 28 \\
\hline a-alanine & 50 & 12 & 400 & 23 \\
\hline$\beta$-alanine & nd & nd & 300 & 24 \\
\hline 4-aminobutanoic acid & nd & nd & 200 & 20 \\
\hline Glycolic acid & nd & nd & 200 & 25 \\
\hline Lactic acid & nd & nd & 300 & 11 \\
\hline Citric acid & nd & nd & nd & nd \\
\hline EDTA & nd & nd & nd & nd \\
\hline
\end{tabular}

nd, non metallic deposit.

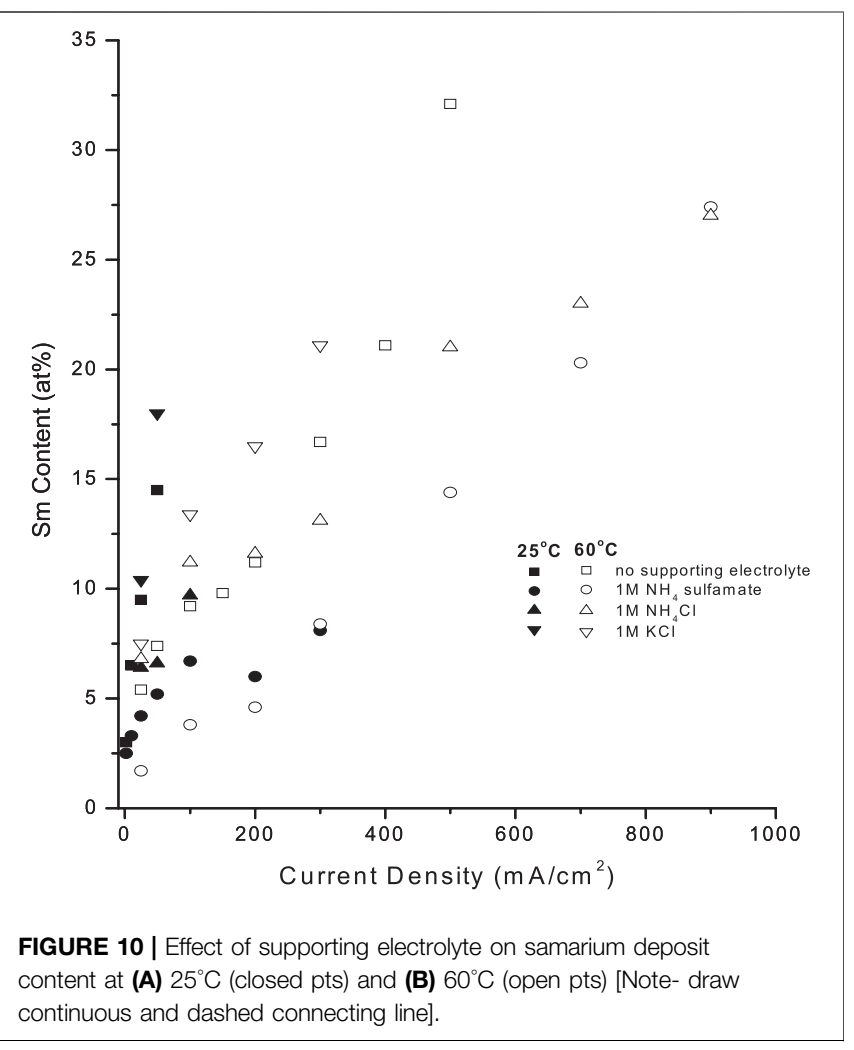

to the deprotonation of ammonium $\left(\mathrm{NH}_{4}{ }^{+} \rightarrow \mathrm{NH}_{3}+\mathrm{H}^{+}\right)$, which could form other competing complexes such as cobalt hexammine ion $\left(\mathrm{Co}\left(\mathrm{NH}_{3}\right)_{6}{ }^{2+}\right)$, favoring Co deposition. Furthermore, $\mathrm{NH}_{3}$ could modify the proposed heteronuclearglycinato-complexes (Schwartz et al., 2004) with the inclusion of bridging $\mathrm{NH}_{3}$ ligands, which are not conductive to facilitate electron transfer in redox reactions (Taube and Gould, 1969).

\section{Proposed Deposition Mechanism}

Coordination compounds, such as inorganic complexes (ligands)-cyanide, halide, hydroxide, and phosphate complexes-, have been employed in electroplating systems since the early 1800 s and are increasingly involved in many commercial processes. Organic ligands including polycarboxylic, hydroxycarboxylic, aminocarboxylic and heterocyclic compounds are also well-known complexing agents for the electrodeposition of single metals and alloys from aqueous plating solutions. Tartrates, citrates, hydroxyacetates, hydroxypropionates and glycinates are extensively employed in electroless deposition and electrodeposition of alloys.

In addition to engineering, electronic, and magnetic applications of these electrodeposited alloys, there is increasing interest in applying compatible samarium (Torres et al., 2001; Torres et al., 2003; Kremer et al., 2005), vanadium (Tsaramyrsi et al., 2001; Kaliva et al., 2002a; Kaliva et al., 2002b), molybdenum and tungsten (Kiss et al., 1995; Zhou et al., 1999; Zhou et al., 2000; Zhang et al., 2003; Zhou et al., 2004; Kustin et al., 2007) coordination compounds in biological (physiological) systems. Citrate ions participate in essential physiological processes (e. g., Krebs cycle) and as natural chelator for various metal ions; compatible amino acid and peptide complexes may interact with bodily citrate fluids and independently have enhanced effects as active biological agents for metalloenzyme processes and oncological treatments.

Yukawa and coworkers stressed the relevance of the coordination chemistry of amino acids and peptides in understanding interaction of trace metals with enzyme and other biological systems in bioinorganic and medicinal chemistry (Komiyama et al., 2008).

Franklin considered possible effects of complexation on electrodeposition mechanisms and deposition rates including adsorption or inclusion of complexed ions or molecules, complexation resulting in catalyzing deposition rate through ion bridging or ion pairing (Franklin, 1987).

The following observations pertinent to the proposed deposition mechanism were considered: only metallic $\mathrm{Co}$ and $\mathrm{Sm}(\mathrm{OH})_{3}$ deposited from Sm-Co solutions. Complexation with glycine or other ligand is a required constituent for electrodeposition of Sm-Co alloys. The structure and geometrics of the complex, along with the deposition variables determined the deposition rates of both Co and Sm, the resultant alloy composition, grain size and other properties. The extensive industrial application of chromium plating was used for 


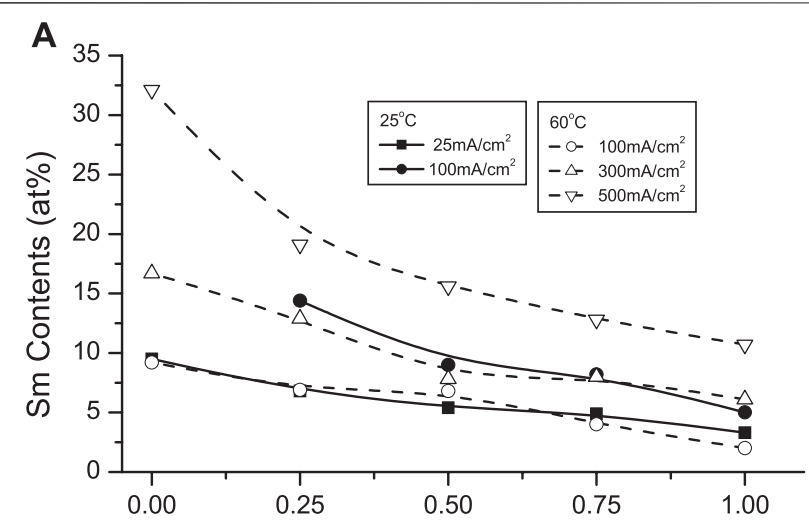

B

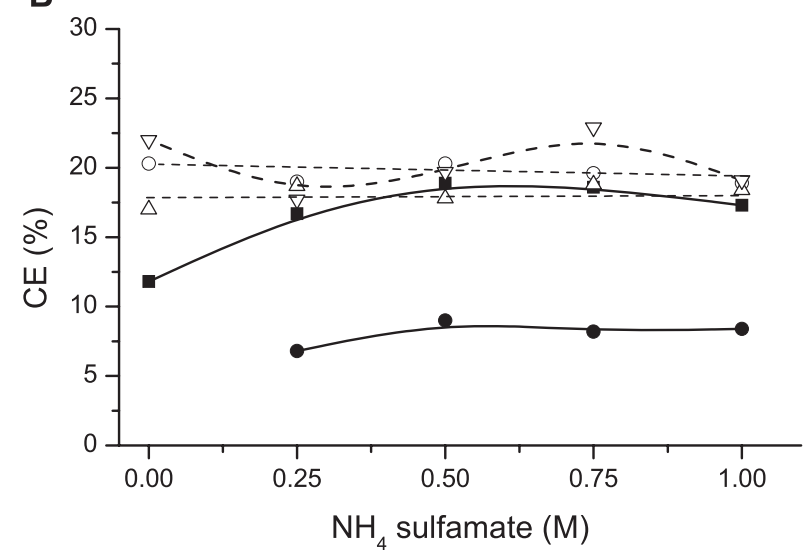

FIGURE 11 | Effect of $\mathrm{NH}_{4}$ sulfamate concentration on (A) samarium deposit content and (B) current efficiency at 25 and $60^{\circ} \mathrm{C}$.

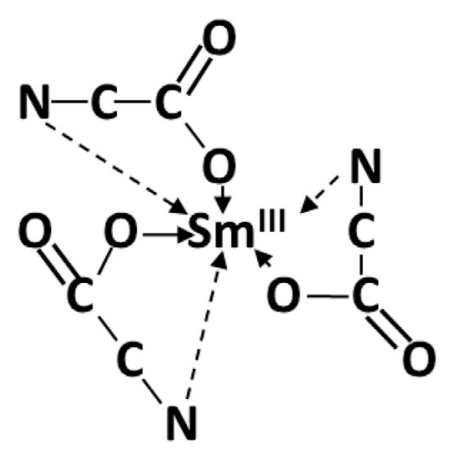

FIGURE 12 | Sm glycine chelate complexes adapted from Prados and Hadjipanayis (1999).

comparison (Hoare, 1989). Although the toxic Cr(VI) regularly electroplates to $\mathrm{Cr}$, much less toxic $\mathrm{Cr}$ (III) cannot. Mandich reported that $\mathrm{Cr}(\mathrm{III})$ is a strongly hydrated ion, which precludes its electrodeposition to metallic Cr (Mandich, 1997). However, complexed with a suitable organic ligand, $\mathrm{Cr}$ (III) deposits to Cr (Danilov and Protsenko, 2001; Song and Chin, 2002).
Yukawa showed the versatility of glycine and other amino acids and peptides as complexing chelated molecules (Komiyama et al., 2008). The versatility of glycine is based, in part, on various protonation/deprotonation configurations. Sm glycinocomplexes either as chelated monomeric Smgly $_{3}$ (Figure 12) or dimeric coordinated compounds, i.e., complexes resulting in high stability constants, possibly preventing electrodeposition (Torres et al., 2001; Torres et al., 2003; Kremer et al., 2005).

Zvaginsteva and Goncharov considered the polymerization of glycine as peptides (Zvaginstev and Goncharov, 1963). It is envisioned that quasi-peptides structures developed as a result of $\mathrm{H}$-bonded bridges by $\mathrm{O}$...H. . . N bonds. The presence of Co ions possibly inhibited Sm-glycine chelated complexes, resulting in catenated heteronuclear trisglycino- complexes coordinating cis oriented Co and Sm ions through the glycine carbonato- and amino- groups, respectively (Figure 13).

In gas phase catalysis, hydrogenation of organics usually proceeds by adsorbed hydrogen atoms on surfaces; this generally requires high temperatures and/or pressures as contrasted with aqueous phase hydrogenation (Ceyer, 2001). Further, in aqueous phase electrocatalysis, adsorbed hydrogen atoms readily reduce and hydrogenate organics and promote polymerization (Parravano, 1951; Park et al., 1985; Li et al., 2012).

$\mathrm{H}$ atoms generated and adsorbed at the cathode surface provided the electrons for the reduction and deposition of metal from the complex. The adsorbed hydrogen atoms reduced $\mathrm{Sm}^{3+}$ to $\mathrm{Sm}^{2+}$, modifying the complex. Continued stepwise reduction by hydrogen atoms resulted in zero-valent $\mathrm{Co}^{0}$ and $\mathrm{Sm}^{0}$ complex, which deposited on the electrode surface, resulting in an intimately mixed deposit constituting the equivalent of an alloy, $\mathrm{Sm}_{\mathrm{x}} \mathrm{Co}_{\mathrm{y}}$, with variable composition, depending on deposition conditions (Figures 13, 14).

Low CD deposition resulted in low Sm content and the presence of Co crystallites in the deposit. The reduction series of $\mathrm{Co}$ and $\mathrm{Sm}$ in the polymeric glycine-complexes and reaction flowchart (Figures 13, 14) show the suggested stepwise reduction process, culminating in the SmCo alloy.

\section{SUMMARY}

Samarium cobalt alloys were electrodeposited from aqueous solutions containing $1 \mathrm{M}$ samarium sulfamate, $0.05 \mathrm{M}$ cobalt sulfate, $0.15 \mathrm{M}$ glycine, in presence and absence of supporting electrolytes. While they contribute to the solution stability, the supporting electrolytes used in this work decreased the Sm content in the deposit. Glycine or other coordination compounds were essential constituents in promoting co-deposition of $\mathrm{Sm}$ and Co; without complexing species, only Co metal and Sm hydroxide or oxide deposited. Glycine was a preferred ligand, resulting in higher deposit Sm contents while effectively inhibiting or minimizing occluded hydroxide/oxides in the deposit.

Polarization curves showed a linear dependence of deposit Sm content on cathodic potential with higher Sm content obtained at more negative potentials than the equilibrium potential of $\mathrm{Sm}$, indicating complex species were involved in the co-deposition mechanism. 
A $\left[\mathrm{H}_{2} \mathrm{~N}-\mathrm{CH}_{2}-\mathrm{C}=\mathrm{O} \ldots \mathrm{H}_{2} \mathrm{~N}-\mathrm{CH}_{2}-\mathrm{C}=\mathrm{O} \ldots \mathrm{H}_{2} \mathrm{~N}-\mathrm{CH}_{2}-\mathrm{C}=\mathrm{O}\right]^{2+}+\mathrm{H}^{0} \rightarrow\left[\mathrm{H}_{2} \mathrm{~N}-\mathrm{CH}_{2}-\mathrm{C}=\mathrm{O} \ldots \mathrm{H}_{2} \mathrm{~N}-\mathrm{CH}_{2}-\mathrm{C}=\mathrm{O}\right]^{2+}+\left(\mathrm{Hgly}^{ \pm}\right)$

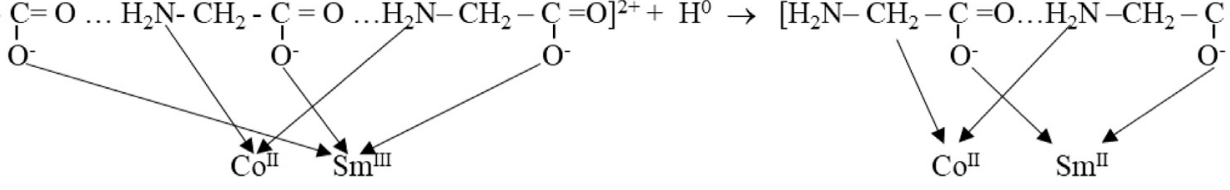

B $\left[\mathrm{H}_{2} \mathrm{~N}-\mathrm{CH}_{2}-\mathrm{C}=\mathrm{O} \ldots \mathrm{H}_{2} \mathrm{~N}-\mathrm{CH}_{2}-\mathrm{C}=\mathrm{O}\right]^{2+}+\mathrm{H}^{0} \rightarrow\left[\mathrm{H}_{2} \mathrm{~N}-\mathrm{CH}_{2}-\mathrm{C}=\mathrm{O} \ldots \mathrm{H}_{2} \mathrm{~N}-\mathrm{CH}_{2}-\mathrm{C}=\mathrm{O}^{+}+\mathrm{H}^{+}\right.$
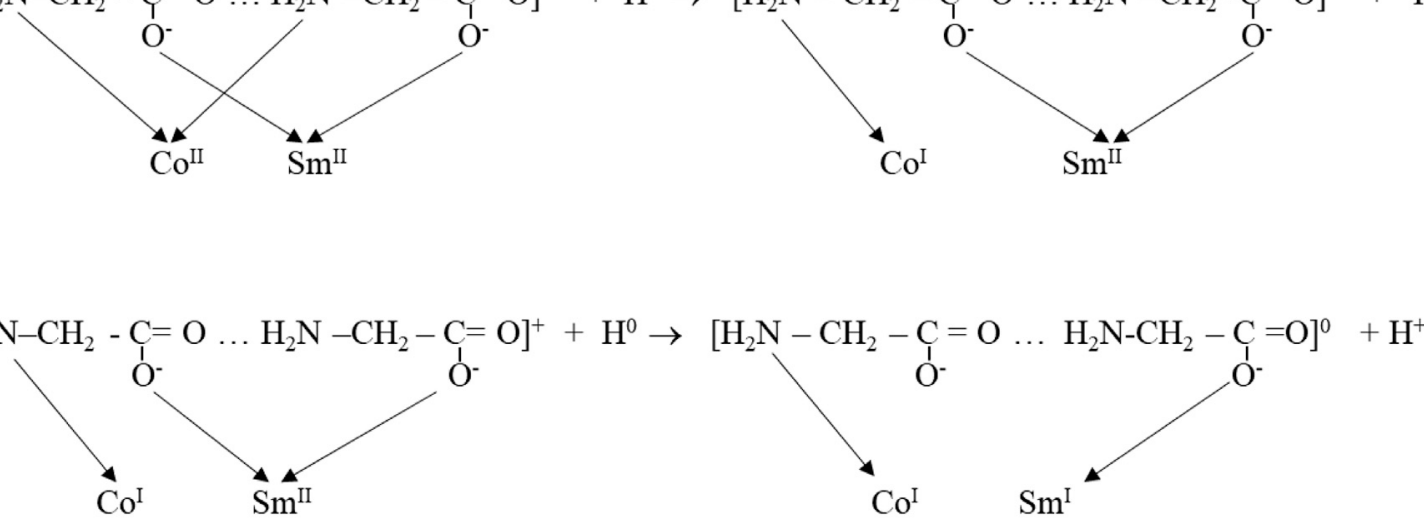

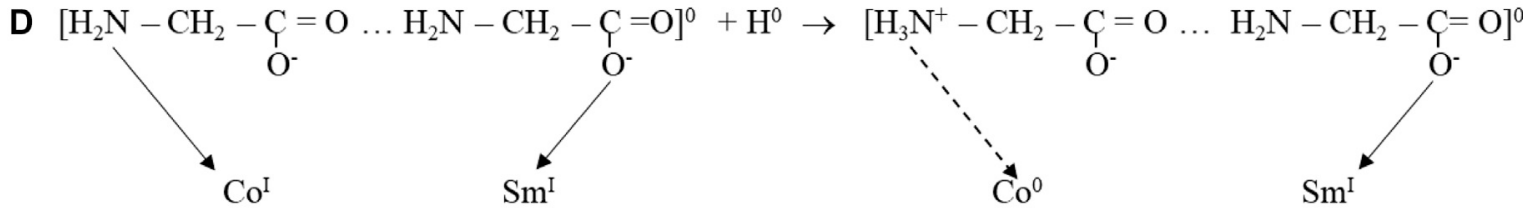

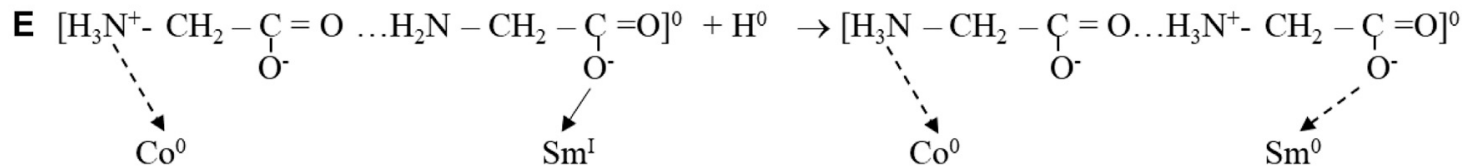

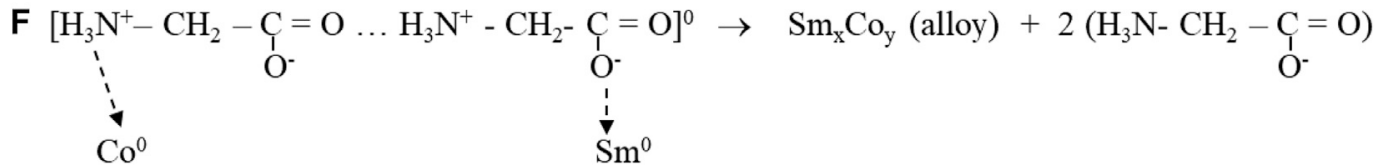

FIGURE 13 | Incremental atomic $\mathrm{H}$ reduction of Sm-Co ions in glycine structure.

Increased solution temperature extended the $\mathrm{CD}_{\max }$ from $50 \mathrm{~mA} /$ $\mathrm{cm}^{2}\left(25^{\circ} \mathrm{C}\right)$ to $500 \mathrm{~mA} / \mathrm{cm}^{2}\left(60^{\circ} \mathrm{C}\right)$, resulting in high deposit $\mathrm{Sm}$ contents (32 at\%), which satisfied the potential stoichiometric SmCo alloy compositions after annealing. The preferred solution $\mathrm{pH}$ range was between 2 and $6 ; \mathrm{pH}>6$ resulted in nonmetallic deposits.

Magnetic saturation $\left(\mathrm{M}_{\mathrm{s}}\right)$ of deposits decreased with increased Sm content, becoming isotropic with deposits containing $>30$ at $\%$ $\mathrm{Sm}$. Electrodeposited SmCo alloys and as-sputtered $\mathrm{SmCo}_{5}$ films exhibited low coercivities (i.e., $\mathrm{H}_{\mathrm{c}}$ of $\sim 100$ Oe as deposited).
Crystalline deposits became noncrystalline (amorphous) with increased deposit Sm content. Lower temperature and lower $\mathrm{CD}$ favor noncrystalline deposits with weak $\mathrm{Sm}(\mathrm{OH})_{3}$ peaks; no $\mathrm{Sm}(\mathrm{OH})_{3}$ peaks are observed in deposits from elevated temperatures.

A deposition mechanism involving the sequential stepwise reduction of the Sm and Co ions complexed with glycine (or other compatible ligand) by atomic hydrogen deposited at the cathode surface is proposed. Without complexation, only metallic Co and non-metallic Sm hydroxide/ oxide co-deposit. 
1) $\mathrm{Co}^{2+}+\mathrm{Sm}^{3+}+3\left(\mathrm{Hgly}^{ \pm}\right) \rightarrow\left[\mathrm{Co}^{\mathrm{II}} \mathrm{Sm}^{\mathrm{III}} \mathrm{gly}^{-3}\right]^{2+}+3 \mathrm{H}^{+}$

2) $\left[\mathrm{Co}^{\mathrm{II}} \mathrm{Sm}^{\mathrm{III}} \mathrm{gly}_{3}^{-}\right]^{2+}+\mathrm{H}^{0} \rightarrow\left[\mathrm{Co}^{\mathrm{II}} \mathrm{Sm}^{\mathrm{II}} \mathrm{gly}^{-2}\right]^{2+}+\left(\mathrm{Hgly}^{ \pm}\right)$

3) $\left[\mathrm{Co}^{\mathrm{II}} \mathrm{Sm}^{\mathrm{II}} \mathrm{gly}_{2}{ }_{2}\right]^{2+}+\mathrm{H}^{0} \rightarrow\left[\mathrm{Co}^{\mathrm{II}} \mathrm{Sm}^{\mathrm{II}} \mathrm{gly}^{-2}\right]^{2+}+\mathrm{H}^{+}$

4) $\left[\mathrm{Co}^{\mathrm{I}} \mathrm{Sm}^{\mathrm{II}} \mathrm{gly}_{2}^{-2}\right]^{+}+\mathrm{H}^{0} \rightarrow\left[\mathrm{Co}^{\mathrm{I}} \mathrm{Sm}^{\mathrm{I}} \mathrm{gly}^{-2}\right]^{0}+\mathrm{H}^{+}$

5) $\left[\mathrm{Co}^{\mathrm{I}} \mathrm{Sm}^{\mathrm{I}} \mathrm{gly}^{-} 2\right]^{0}+\mathrm{H}^{0} \rightarrow\left[\mathrm{Co}^{0} \mathrm{Sm}^{\mathrm{I}}\left(\mathrm{gly}^{-} \mathrm{Hgly}^{ \pm}\right)\right]^{0}$

6) $\left[\mathrm{Co}^{0} \mathrm{Sm}^{\mathrm{I}}\left(\mathrm{gly}^{-} \mathrm{Hgly}^{ \pm}\right)\right]^{0}+\mathrm{H}^{0} \rightarrow\left[\mathrm{Co}^{0} \mathrm{Sm}^{0} \mathrm{Hgly}^{ \pm 2}\right]$

7) $\left[\mathrm{Co}^{0} \mathrm{Sm}^{0} \mathrm{Hgly}^{ \pm 2}\right] \rightarrow \mathrm{CoSm}$ (alloy) $+2\left(\mathrm{Hgly}^{ \pm}\right)$

FIGURE 14 | Proposed stepwise reduction of Sm-Co glycine complexes by $\mathrm{H}$ atoms.

\section{AUTHOR'S NOTE}

This manuscript is dedicated to the pioneering research accomplishments of Dr. Ken Nobe and Mr. Morton Schwartz, who recently passed away. They were world-renowned

\section{REFERENCES}

Adachi, H., Kimura, K., and Ino, H. (1994). Magnetic Properties of Metastable h.c.P. Samarium. Mater. Sci. Eng. A 181, 864-867. doi:10.1016/0921-5093(94) 90757-9

Bozorth, R. M. (1978). Ferromagnetism. New York: IEEE Press.

Cavallotti, P., Galbiati, E., and Chen, T. (1983). Electroplating Engineering and Waste Recycle. Pennington, NJ: Electrodeposition Division, Electrochemical Society.

Ceyer, S. T. (2001). The Unique Chemistry of Hydrogen beneath the Surface: Catalytic Hydrogenation of Hydrocarbons. Acc. Chem. Res. 34 (9), 737-744. doi:10.1021/ar970030f

Chen, L., Schwartz, M., and Nobe, K. (1996). Electrodeposited Magnetic Thin Films, Electrochemically Deposited Thin Films III, in PV 96-19. Editors M. Paunovic and D. A. Scherson (San Antonio, TX: The Electrochemical Society Proceedings Series).

Cho, H. S., Salem, J. R., Kellock, A. J., and Beyers, R. B. (1997). Magnetic and Electrical Properties of Co-sm Thin Films Deposited by Dc Magnetron Sputtering. IEEE Trans. Magn. 33 (5), 2890-2892. doi:10.1109/20.617788

Danilov, F. I., and Protsenko, V. S. (2001). Kinetics and Mechanism of Chromium Electroplating from Cr(III) Baths. Prot. Met. 37 (3), 223-228. doi:10.1023/a: 1010490126064

Dini, J. (1993). An Electroplater's View of PVD Processing. Plating Surf. finishing 80, 26.

Diven, C. F., Wang, F., Abukhdeir, A. M., Salah, W., Layden, B. T., Geraldes, C. F. G. C., et al. (2003). Evaluation of [Co(gly)3]-As a35Cl-NMR Shift electrochemical engineers and electroplaters known for their research on electrochemical processes including kinetics and mechanisms of electrodissolution, electrodeposition, corrosion, electrochemical energy systems, and bioelectrochemistry. This manuscript was the last manuscript they worked on together.

\section{DATA AVAILABILITY STATEMENT}

The original contributions presented in the study are included in the article/supplementary material, further inquiries can be directed to the corresponding author.

\section{AUTHOR CONTRIBUTIONS}

JW conducted most of the experimental work. NM is assisted the submission process, revised the manuscript during review and has agreed to serve as corresponding author.

\section{FUNDING}

This work was supported in part by the NSF XYZ on a chip program (Award \#0089095).

\section{ACKNOWLEDGMENTS}

Special thanks to J. Schwartz for assistance with the figures and submission. KN has not seen this submitted version; MS and NM are responsible for any errors.

Reagent for Cellular Studies. Inorg. Chem. 42 (8), 2774-2782. doi:10.1021/ic0258680

du Trémolet Lacheisserie, É., Gignoux, D., and Schlenker, M. (2002). Magnetism: II-Materials and Applications. US: Springer.

Franklin, T. C. (1987). Some Mechanisms of Action of Additives in Electrodeposition Processes. Surf. Coat. Technol. 30 (4), 415-428. doi:10.1016/0257-8972(87)90133-2

Hoare, J. P. (1989). An Electrochemical Mystery story: a Scientific Approach to Chromium Plating. Plat. Surf. Finish. 76 (9), 46-52.

Kaliva, M., Giannadaki, T., Salifoglou, A., Raptopoulou, C. P., and Terzis, A. (2002a). A New Dinuclear Vanadium(V)-Citrate Complex from Aqueous Solutions. Synthetic, Structural, Spectroscopic, and pH-dependent Studies in Relevance to Aqueous Vanadium(V)-Citrate Speciation. Inorg. Chem. 41 (15), 3850-3858. doi:10.1021/ic010971v

Kaliva, M., Kyriakakis, E., and Salifoglou, A. (2002b). Reactivity Investigation of Dinuclear Vanadium(IV,V)-Citrate Complexes in Aqueous Solutions. A Closer Look into Aqueous Vanadium-Citrate Interconversions. Inorg. Chem. 41 (26), 7015-7023. doi:10.1021/ic020323r

Kiss, T., Buglyó, P., Sanna, D., Micera, G., Decock, P., and Dewaele, D. (1995). Oxovanadium(IV) Complexes of Citric and Tartaric Acids in Aqueous Solution. Inorg. Chim. Acta 239 (1), 145-153. doi:10.1016/0020-1693(95) 04750-6

Komiyama, T., Igarashi, S., and Yukawa, Y. (2008). Synthesis of Polynuclear Complexes with an Amino Acid or a Peptide as a Bridging Ligand. Curr. Chem. Biol. 2, 18. doi:10.2174/187231308784220509

Kremer, C., Torres, J., Dominguez, S., and Mederos, A. (2005). Structure and Thermodynamic Stability of Lanthanide Complexes with Amino Acids 
and Peptides. Coord. Chem. Rev. 249 (5), 567-590. doi:10.1016/ j.ccr.2004.07.004

Kustin, K., Pessoa, J. C., and Crans, D. C. (2007). "Vanadium: the Versatile Metal," in ACS Symposium Series 974. Editors K. Kustin (Brandeis University), J. C. Pessoa (ISTTechnical University of Lisboa), and D. C. Crans (Colorado State University) (Washington, D.C.: American Chemical Society), 4206. 978-0-8412-7446-4. (distributed by Oxford University Press).

Li, Z., Kelkar, S., Lam, C. H., Luczek, K., Jackson, J. E., Miller, D. J., et al. (2012). Aqueous Electrocatalytic Hydrogenation of Furfural Using a Sacrificial Anode. Electrochimica Acta 64, 87-93. doi:10.1016/ j.electacta.2011.12.105

Mandich, N. V. (1997). Chemistry \& Theory of Chromium Deposition: Part I - Chemistry. Plating Surf. Finishing 84 (5), 108-115.

Myung, N. V., Schwartz, M., and Nobe, K. (1999). Fundamental Aspects of Electrochemical Deposition and Dissolution. NJ: Pennington.

Park, K., Pintauro, P. N., Baizer, M. M., and Nobe, K. (1985). Flow Reactor Studies of the Paired Electro-Oxidation and Electroreduction of Glucose. J. Electrochem. Soc. 132 (8), 1850-1855. doi:10.1149/1.2114229

Parravano, G. (1951). Polymerization Induced by Hydrogen in Metals*. J. Am. Chem. Soc. 73 (2), 628-630. doi:10.1021/ja01146a039

Prados, C., and Hadjipanayis, G. C. (1998). Magnetic and Structural Properties of High Coercivity $\mathrm{Sm}(\mathrm{Co}, \mathrm{Ni}, \mathrm{Cu})$ Sputtered Thin Films. J. Appl. Phys. 83 (11), 6253-6255. doi:10.1063/1.367804

Prados, C., and Hadjipanayis, G. C. (1999). Sm(Co, Cu, Ni) Thin Films with Giant Coercivity. Appl. Phys. Lett. 74 (3), 430-432. doi:10.1063/1.123051

Ruan, S., and Schuh, C. A. (2008). Mesoscale Structure and Segregation in Electrodeposited Nanocrystalline Alloys. Scripta Materialia 59 (11), 1218-1221. doi:10.1016/j.scriptamat.2008.08.010

Schwartz, M., et al. 1999.

Schwartz, M., Myung, N. V., and Nobe, K. (2004). Electrodeposition of Iron Group-Rare Earth Alloys from Aqueous Media. J. Electrochem. Soc. 151 (7), C468. doi:10.1149/1.1751196

Song, Y. B., and Chin, D.-T. (2002). Current Efficiency and Polarization Behavior of Trivalent Chromium Electrodeposition Process. Electrochimica Acta 48 (4), 349-356. doi:10.1016/s0013-4686(02)00678-3

Strnat, K. J., and Strnat, R. M. W. (1991). Rare Earth-Cobalt Permanent Magnets. J. Magnetism Magn. Mater. 100 (1), 38-56. doi:10.1016/0304-8853(91)90811-n

Taube, H., and Gould, E. S. (1969). Organic Molecules as Bridging Groups in ElectronTransfer Reactions. Acc. Chem. Res. 2 (11), 321-329. doi:10.1021/ar50023a001

Torres, J., Kremer, C., Kremer, E., Pardo, H., Russi, S., Mombrú, Á., et al. (2003). Sm(III) Complexation with Small Peptides. Crystal Structure of [Sm2(Gly-Val) 4(H2O)8](ClO4)6·2H2O. Inorg. Chim. Acta 355, 442-448. doi:10.1016/s00201693(03)00373-6

Torres, J., Kremer, C., Kremer, E., Pardo, H., Suescun, L., Mombru, Á., et al. (2001). Sm(III) Complexation with a-amino Acids. J. Alloys Compd. 323-324, 119-124. doi:10.1016/s0925-8388(01)00979-3
Tsaramyrsi, M., Kaliva, M., Salifoglou, A., Raptopoulou, C. P., Terzis, A., Tangoulis V., et al. (2001). Vanadium(IV)-Citrate Complex Interconversions in Aqueous Solutions. A pH-dependent Synthetic, Structural, Spectroscopic, and Magnetic Study. Inorg. Chem. 40 (23), 5772-5779. doi:10.1021/ic010276n

Wei, J. C., Schwartz, M., and Nobe, K. (2008). Aqueous Electrodeposition of SmCo Alloys. J. Electrochem. Soc. 155 (10), D660. doi:10.1149/1.2961013

Wei, J. C., Schwartz, M., and Nobe, K. (2006). Parametric Aqueous Electrodeposition Studies of Co-sm Alloys. ECS Trans. 1 (4), 273-278.

Wei, J., Schwartz, M., and Nobe, K. (2009). DC Aqueous Electrodeposition of Sm-Co Permanent Magnets. ECS Trans. 16 (45), 129.

Zhang, H., Zhao, H., Jiang, Y.-Q., Hou, S.-Y., Zhou, Z.-H., and Wan, H.-L. (2003). $\mathrm{pH}$ - and Mol-Ratio Dependent Tungsten(VI)-citrate Speciation from Aqueous Solutions: Syntheses, Spectroscopic Properties and crystal Structures. Inorg. Chim. Acta 351, 311-318. doi:10.1016/s0020-1693(03)00177-4

Zhou, Z.-H., Hou, S.-Y., and Wan, H.-L. (2004). Peroxomolybdate(vi)-citrate and -malate Complex Interconversions by $\mathrm{pH}$-Dependence. Synthetic, Structural and Spectroscopic Studies. Dalton Trans. (9), 1393-1399. doi:10.1039/ b315280d

Zhou, Z.-H., Wan, H.-L., and Tsai, K.-R. (1999). Bidentate Citrate with Free Terminal Carboxyl Groups, Syntheses and Characterization of Citrato Oxomolybdate(VI) and Oxotungstate(VI), $\Delta / \Lambda-\mathrm{Na} 2[\mathrm{MO} 2(\mathrm{H} 2 \mathrm{cit}) 2] \cdot 3 \mathrm{H} 2 \mathrm{O}$ $(\mathrm{M}=\mathrm{Mo}$ or W). J. Chem. Soc. Dalton Trans. (24), 4289-4290. doi:10.1039/ a908739g

Zhou, Z.-H., Wan, H.-L., and Tsai, K.-R. (2000). Syntheses and Spectroscopic and Structural Characterization of Molybdenum(VI) Citrato Monomeric Raceme and Dimer, $\mathrm{K} 4[\mathrm{MoO} 3(\mathrm{cit})] \cdot 2 \mathrm{H} 2 \mathrm{O}$ and $\mathrm{K} 4[(\mathrm{MoO} 2) 2 \mathrm{O}$ (Hcit)2].4H2O. Inorg. Chem. 39 (1), 59-64. doi:10.1021/ic990042s

Zvaginstev, O. E., and Goncharov, E. V. (1963). Russ. Inorg. Chem. 8, 179.

Conflict of Interest: The authors declare that the research was conducted in the absence of any commercial or financial relationships that could be construed as a potential conflict of interest.

Publisher's Note: All claims expressed in this article are solely those of the authors and do not necessarily represent those of their affiliated organizations, or those of the publisher, the editors and the reviewers. Any product that may be evaluated in this article, or claim that may be made by its manufacturer, is not guaranteed or endorsed by the publisher.

Copyright (c) 2021 Wei, Schwartz, Nobe and Myung. This is an open-access article distributed under the terms of the Creative Commons Attribution License (CC BY). The use, distribution or reproduction in other forums is permitted, provided the original author(s) and the copyright owner(s) are credited and that the original publication in this journal is cited, in accordance with accepted academic practice. No use, distribution or reproduction is permitted which does not comply with these terms. 